\title{
THE ANNALS OF IOWA.
}

BY THE

\section{State Mistorical Soriety.}

IOW A CITY, OCTOBER, 1865.

\section{INUMBER XII.}

SKETCHES OF THE SAC AND FOX INDIANS, AND THE EARLY SETTLEMENT OF W APELLO COUNTY.

BY URIAH BIGGS.

\section{AGENCY AND INDIANS.}

The other chiefs of the tribe were Pash-a-pa-ho and Hard. Fish, who have already been incidentally noticed, and also Wapello and Appanoose who were chiefs and Wab-e-kei-sheik the prophet of the tribe, and who wielded more infuence in its internal affairs than any of the subordinate chiefs. Pash. a-pa-ho was chief of the Musquakies or Foxes, and lived on the Iowa River with that portion of the confederated tribes till the time of their removal West of the Missouri.

I will now return to the thread of events I proposed to follow in the commencement of this sketch, some of which are already noticed in introducing the actors in them.

In 184 -General Joseph M. Street was transferred from the agency of the Winnebagoes at Prairie-du-Chien, to establish all agency among the Sacs and Foxes, and these tribes were placed under his charge. 
The site was selected within the present limits of Wapello county, and near the present town of "Agency City." $\mathrm{He}$ constructed a comfortable frame building, with the necessary rooms for residence of his family, and improved a large farm with the necessary farm buildings, at the expense of the Indian fund. These provisions were made for the support of the family of the agent over and above his salary. An addi. tional public expense was incurred in improving and furnishing with the necessary implements, a large farm on a very eligible site adjacent to the Agency farm proper. This was denominated "the pattern farm," and a salaried agent was employed to take it in charge and superintend its cultivation and the management and disposal of the crops. The arowed object of this expenditure was to set the Indians a pattem in agriculture, and entice them to its practice by the solid advantages they were to derive from the annual yield, in the sustenance it might afford themselves and ponies during the winter. There was still further prorisions made for the Indians' converiences in managing their crops of grain, in constructing two mills, one on Soap Creek, and one on a small creek now called Sugar Creek, and situated immediately below the present Rail Road crossing. This latter was swept away by a flood in the stream soon after its erection. The one erected on Soap Creek had some permanency, and continued for many years to be of service to the builder and subsequent owners. But to the Indians these extensive outlays affurded no solid benefit - they were not allured from their idle, dissipated life, and their ponies had to subsiat on moss and buds during the winter as before. Capt. George Wilson, a son-in-law of Gen. Street, held the possessory right fo the "pattern farm," at the time of the purchase of the country from the Indians, and obtained a patent for it by paying a small fraction over the price of other and unimproved government lands. The Agency farm proper was ceded to Mrs. Eliza M. Street, relict of Gen. Street, in the treaty of 
eighteen hundred forty-two, by the Indians. Both Wapello and Gen. Street having died prior to the treaty and were buried fraternally side by side in the farm garden, it was therefore held as sacrilege by Keokuk to permit the section of land containing these sacred relics to run the hazard of falling into the hands of a stranger, and it was reserved for the widow, and the title subsequently confirmed.

As attaches to the Agency, Joseph Smart the interpreter, and Baker, the Blacksmith, were permitted to select sites and make farms adjacent to it. John Goodell, the interpreter for Hard Fish's band, improved the site of the present residence of T. C. Ogden, Esq., fonr miles below Eddyville, and Jeremiah Smith, Senior, established the farm at the mill site on Sugar Creek, now owned by the Messrs. Wood. In addition to these improvements by white men, three of the Indian chiefs, Keokuk, Wapello and Appanoose, had each a large field improved, the two former on the right bank of the Des Ioines, laying back from the river, in what is now called the "Keokuk prairie," and the latter, in opposition to the wishes of the other chiefs, established his village on the present site of the city of Ottumwa, and had a field improved immediately below, embracing the site of the Rail Road depot. He persisted in selecting this side of the river for his residence, in opposition to the expressed wishes of Keokuk and Wapello who desired him to settle on the same side with themselves, and, for this persistence, the Indians give his place the name of Ot-tum-wah-noc, which, as interpreted by themselves to the writer, signifies a place of perseverance or self-will. From this the city of Ottumwa derived its name.

Two old Indian trading firms established trading houses under this agency. The Messrs. Ewings, of Indiana, selected for their trading post the site of the farm now owned by Mr. Trout, and improved the field lying on both sides of the Rail Road track. The Messrs. Phelps, of Illinois, established their post about one mile below, at a place long known as the "Old Garrison." These old traders had a competitor but newly 
embarked in the Indian trade, in the person of J. P. Eddy, of Saint Louis, who established his post at what is now the site of Eddyville. The two former were the favorites of Keokuk's band and the agency pets, and the latter was most favored by Hard Fish's band-this chief building his town in the immediate vicinity of Eddy's trading house, and the prophet, who adhered to this faction, established his town on the right bank of the river, one mile above, which is now owned by $\mathrm{Mr}$. Henry O'Rielly, of New York.

The Indians thus circumstanced were thrown out of their natural element and, no longer accustomed to rely on their exertion in the chase, looked mainly to their annuities for sustenance. They became idle and listless, and in the absence of their natural and wonted excitements, plunged themselves into the depths of dissipation. Though heavy penalties were fixed in the law of Congress regulating intercourse with In. dian tribes, against furnishing them with whiskey, and though impotent threats were made from time to time against the violators of the law by those to whom its execution was committed, the Indians, nevertheless, found abundant opportunity to purchase all the whiskey they wanted and could pay for. They appeared not to drink for social glee, but each one that determined to get drunk, apportioned his dose, drank it, in order to produce a frantic excitement in the shortest time possible. Generally in these orgies, a portion of them remained sober, to prevent those that were intoxieated from doing excessive mischief. This duty, however, was mostly discharged by the squaws, who, as a precaution, secreted the knives and tomahawks, and other daugerous implements, and provided themselves with thongs, and when the inebriates become too obstreperous, they tied them neck and heels, so that they could only roll over like a ball. The pleadings for mercy, or the threads of vengeance by the bacharial at the sight of thongs had no effect on these guardians of his and their safety, but they good humoredly executed their duty, and when the fumes of liquor had passed away, and the prisoner was sober enough to 
be released, he seemed perfectly reconciled to the treatment. Notwithstanding these guards placed over these bachanalian revels, many accidents happened in them to life and limb, and caused sickness and an increase of mortality to the tribe. During Hard Fish's residence at Eddyville, his band was severely afflicted with fatal diseases, and the grave yard, situated within the present limits of Eddyville, became a quite populous part of the village.

The winter (of eighteen hundred and forty-two and fortythree) before their removal above the temporary line at Red Rock, happened to be one of unusual severity and durationcommencing on the eleventh day of Norember and continuing to the middle of April, and caused them much suffering and a heary loss in ponies from starvation. The prophet, who had not approved the treaty, attributed this calamity to the displeasure of the Great Spirit for selling their country, and many religious rites were performed to atone for the crime.

The most striking of these rites that I observed, was the sacrifice of a living dog. The victim was forcibly lashed to a tree several feet above the ground, his back resting against the tree, and tightly bound with thongs passing around his throat and other parts of tha body, leaving the legs free, and in a hanging posture. To the toes of each foot, was suspended a medicine bag, and the victim thus left to expire, and his body to waste on the altar after their departure.

When the time for their final departure from Ot-tum-wahnoc arrived, a solemn and impressive silence pervaded the camp, and the faces of many of their stoutest men were bathed in tears, and as the cavalcade got fairly in motion, there was 2 general outburst of frantic griefs, fully impressing upon the spectator a feeling of pity and deep commiseration for their fate.

Great solemnity and apparently sincere devotion attend the performance of their religious rites. Their evening orisons, performed in a solemn low chant through the several lodges of a large encampment, inspire the considerate listener with ven- 
eration and awe. Their religion is based on a sublime conception of nature in which they see the manifestations of the supervision and power of a supreme intelligenee which they denominate the Great Spirit, to whom they pray with devout adoration. Of the truth of their religious conceptions they are as firmly convinced and adhere to it with as much tenacity as other religionists do to their peculiar and varied theories.

They are fast wasting away under the influence of civilization and the onward march of the white race, and it is probable before the approach of another century, oblivion will have closed its curtains over the last of their race.

\section{SETTLEMENT.}

The great value of this country in an agricultural estimate made it a matter of the highest importance to the Territory and embryo State to extinguish the Indian title at as early a day as could be practicable, and to bring about this strongly desired result, a treaty was proposed in the fall of 1841 . The high hopes entertained of a successful result eaused a rush of immigrants to the vicinity of the boundary. The greatest press was along the Des Moines, and the present territory of Wapello county, seemed the place of greatest attraction. Six individuals associated themselves together to ascertain, by $\approx$ line run and measured from the public surveys, the centre of the county that would necessarily be organized here. This company primarily comprised the followiug names, viz: J. R. McBeth, John D. Elbert, Uriah Biggs, Milton Jameson, William Ross and David Glass, and subsequently Paul C. Jeffries and Hugh George became associated with it in its early action. The centre point was ascertained to be within the present limits of the city of Ottumwa, and a prospective claim sketched out without marking the trees, as that would have been held an act of trespass in the Indian country. The sanguine bofes indulged in of a treaty were docmed to disap pointment, however, for the present. 
Mr. James Jordan, who had been connected with the Indian trade, had, by the permission of some of the subordinate chiefs or head men, settled upon and improved a large farm in the Iowaville prairie adjacent to the boundary and within the limits of the Indian territory, and the impulse given by the profpect of a treaty to the tide of immigration, caused others to break over the line, and make settlements upon the Indian lands, of which the Indians very justly complained. Capt. John Baach, then in charge of the agency, remonstrated against this palpable infraction of the rights of the Indians, and warned these settlers to leave and recross the boundary, which warning they disregarded, and persisted in their occupancy of the country. It now became the duty of the agent to call in the aid of the dragoons to make a compulsory removal of these intruders. The discharge of this unpleasant duty was committed to the discretion of Lient. Ruff, who performed it in as forbearing and mild a manner as the circumstances would permit. The household effects were carefully removed, and the cabin and fences were burned down. Mr. Jordan, too, shared the fate of the other settlers. His dwelling, a well constructed double hewed log house, was committed to the flames, but he was permitted to remove his rails over the boundary, where he preserved them until the treaty was made and possession legally acquired, when he rebuilt his farm where he now resides in a finely constructed mansion.It required the continued presence of the dragoons in the country, and their constant vigilance to restrain the impatience of the immigrants on the border from breaking over and marking out the country into claims, and taking other steps in form ing settlements. After the treaty was concluded in the fall of 1842, and prior to the flrst day of the following May, the time agreed upon in the treaty for the Indians to yield possession of the country as high up as the river of Red Rock, the people had permission to freely explore the country, but were restrained from marking lines or making other evidences of location, and the dragoons regularly patrolled the conntry to pre- 
rent the abuse of this privilege, and by the time of the arrival of that day, so memorable in the history of Wapello county, the country had been thoroughly explored and imaginary lines of claims projected throughout this county, and the territory of several other counties in the purchase. It was important in maintaining a right to a claim in the courts, that it should be made after the complete extinguishment of the Indian title, and as that title expired on the first day of May, and as the legal day commenced at midnight, extraordinary preparations were made for effective operations at that eventful hour.

To aid in an approach to accuracy, in some cases piles of dry wood were piled on the rising grounds along the projected boundaries, and were fired a short time previous to twelve o'clock - time pieces were held at various stations throughout the country, and when the momentous hour had fairly arrived, it was announced by the discharge of fire arms, and answered in like manner thoughout the country. A scene then ensued which, if it could have been viewed thronghont by a calm dibinterested spectator, would have offered a rich fund of amusement. The night was dark, the stars furnished a too feeble light for the necessity of the moment, but every one pressed forvard in the execution of his purpose by torch light and starlight and in darkness, with axe and hatchet, blazing lines with all possible courses, corners and angles, crossing and re-crossing their neighbor's track, and overlapping each other's claims, and leaving strips and gores of unclaimed territory between, creating a chaos of lines and tracts of interminable confusion. When daylight revealed the results of the night's labor, altereations arose, and compromises were generally effected without serious difficulty or personal violence. A large number whose families were in readiness on the boundary line, moved over during the day with their stock and implements of husbandry, and took full and legal possession of their claims, and between midnight and sun down of that one day, there were at least one thousand settlers within the present limits of the county occupying in good faith. 
The surrey of "Ottumwa" was immediately made by the association above named, embracing about four hundred lots, and each alternate lot throughout the plat was reserved as a bonus to the county for the seat of justice, which arrangement was finally, after much expense to the company, entered into by the county commissioners, and the county received a gratuity of over two hundred lots laid off and recorded, beside the use and exclusive occupancy of a suitable building for holding courts and for public offices, for a period of ten years. The commissioners appointed by the Legislature to locate the seat of Justice, fixed on Ottumwa, and finding the town laid off and recorded, omitted to mention its name as is usually done by similar boards. They only mentioned the quarter section in their report, and the County Board wishing to show some impress of their labors on the capital of the county, they changed the name to that of Lonisville. The town company made a strong remonstrance to this change, desiring to retain the Indian name as a matter of taste, and aroid the confusion attending the adoption oi the name of other towns in the country. They, however, finally yielded and permitted the record to be changed, with the intention of appealing to the Legislature for its restoration. A struggle for a post office under the several names was at once set in motion, in which the company were successful, and the Post Office was known as Ottumwa, while the town was legally called Lonisville. The next Legislature blotted out Louisville without even an effort of its friends to sare it. Eddyville, Agencyi City and Dahlonega were all laid out and commenced their growth among the first improvements of the county, and the latter preferred its claims for the county seat, but met no favor with the locating commissioners.

The succeeding history of Wapello county, has been written by Dr. G. R. Boyd, Esq., for the use of the Historical Society. 
Copyright of Annals of Iowa is the property of State of Iowa, by \& through the State Historical Society of Iowa and its content may not be copied or emailed to multiple sites or posted to a listserv without the copyright holder's express written permission. However, users may print, download, or email articles for individual use. 